\title{
Nigeria: Her Neighbours and the Fight against Terrorism in the Lake Chad Basin Region
}

\author{
Ibrahim M. Jumare, Abubakar Sama'ila*
}

Department of History, Usmanu Danfodiyo University, Sokoto-Nigeria

DOI: $10.36347 /$ sjahss.2020.v08i06.004

| Received: 25.03.2020 | Accepted: 01.04.2020 | Published: 26.06.2020

*Corresponding author: Abubakar Sama'ila

\section{Abstract}

Since 2011, Nigeria has been facing Boko Haram terrorists activities. The trend is multidimensional: from complex security challenges, ranging from transnational organized crime, terrorism and proliferation of advanced and light weapons, to the simple and common security challenges. More disturbing was the protracted and internationalized insurgent activities of Boko Haram elements of north-eastern areas of Nigeria. Over the course of less than two decades Boko Haram has morphed from a terrorists group operating within Nigeria to a regional terror group with a regional presence across multiple countries in West Africa and beyond but also gradually spreading to a large portion of the Lake Chad Basin. Taking into cognizance that Nigeria is the main victim of the insurgency, has been the center piece upon which the regional security framework performs or operates. The main issue addressed in this paper is to appraise how the countries of the region approached security challenges collectively. The paper further, analyses the modus operandi of the Nigerian state through regional cooperation to tackle terrorist activities in the Lake Chad Basin region of West Africa. To do this, the paper looks at the bases for security cooperation between Nigeria and her neighbors in line with the ECOWAS security framework. Using the ECOWAS, we intend to interrogate the following questions; What is the nature of Nigeria's cooperation with her neighbors in tackling terrorism especially in the Chad Basin area? What are the mechanisms put in place in the fight against terrorists' activities and, why is it that there are increases in these attacks in spite of the presence of numerous regional and sub- regional joint task forces in the area? Keywords: Nigeria, Terrorism, Boko Haram, Regional Cooperation, Lake Chad Basin.

Copyright @ 2020: This is an open-access article distributed under the terms of the Creative Commons Attribution license which permits unrestricted use, distribution, and reproduction in any medium for non-commercial use (NonCommercial, or CC-BY-NC) provided the original author and source are credited.

\section{INTRODUCTION}

Since about the last 10 years the Nigerian media has continuously been awash with various reports on terrorist activities ranging from suicide bombings, targeted attacks on security agencies, public organizations, sacred places such as churches and mosques as well as public facilities, including schools. From 2009, insecurity linked to the insurgency of Boko Haram group and its repercussion spreads from the heart of Borno state to the entire north-east of Nigeria and then to the border areas of neighboring countries: Cameroon, Niger and Chad. Since 2013, the Boko Haram terrorist group has frequently attacked cities, towns and villages, security outposts and schools, and has also kidnapped male and female civilians, foreign tourists and missionaries [1]. The crisis has progressively affected the entire region of Lake Chad which is one of the great cross-border areas of the Sahelian Africa at the crossroads of Africa savannahs and desert of West Africa and Central Africa [2]. Recently, there have been an increasing number of attacks in the Lake Chad Basin region along Nigeria's borders with the republic of Chad and Cameroon and also in the northern provinces of Cameroon [3]. In early January 2015, Boko Haram overran a military base in northeastern Nigeria which was the headquarters of the Multinational Joint Task Force (MNJTF) located in Baga, Borno State. The group then forced thousands of people out of the region, burnt and destroyed homes and businesses, and committed mass killings. Again, in November 2018, Boko Haram attacked a military garrison in Borno killing at least 80 Nigerian soldiers [4].

Originating in the north-east, Boko Haram insurgency has been ongoing for the past ten years as shown above, gradually spreading to other parts of the country as well as to a large portion of the Lake Chad Basin. In response to the scourge which threatens not only Nigeria's territorial integrity and regional stability, the concerned countries: Cameroon, Niger and Chad stepped up their military responses. These international initiatives become the joint efforts that led to the 
establishment of the Multinational Joint Task Force (MNJTF) under the auspices of the Lake Chad Basin Commission (LCBC). Its establishment under its current structure was determining by the LCBC heads of state and government during the Extraordinary Summit of the LCBC member states and Benin in Niamey, Niger on $7^{\text {th }}$ October 2014 [5]. The mandate of the MNJTF as outlined in the AU communique of the $567^{\text {th }}$ PSC meeting, is to ...create a safe and secure environment in the areas affected by the activities of Boko Haram and other terrorist groups...facilitate the implementation of overall stabilization programmes by the LCBC member States and Benin Republic in the affected areas, including the full restoration of state authority and the return of IDPs (Internally Displaced People) and Refugee; and facilitate, within the limit of its capabilities, humanitarian operations and the delivery of assistance to the affected populations [3]

With regard to the military component, the operational headquarters of the MNJTF are based in N'Djamena (Chad) and consist of military and security personnel from the various forces of the contributing countries. They exercise command and control of the force and coordinate the military actions of the troops of the contributing countries. Consequent upon series of attacks across the countries of Lake Chad Basin, Muhammadu Buhari, the Nigeria's president who chaired the special Summit of Heads of State and Government of the Lake Chad Basin Commission (LCBC) in December, 2018, emphasized the need and determination of MNJTF forces to win the war against terrorism in the Lake Chad Basin. Prior to the 2018 Summit, there was the A.U Commission on Regional and International efforts to combat terrorism. At its Summit meeting on terrorism and violent extremism held in Nairobi on the $2^{\text {nd }}$ September 2014, the issue of Boko Haram was discussed extensively [3]. More specifically, the Council urged the countries of the region to take the necessary steps towards operationalizing the mechanisms agreed upon to address more effectively the threat posed by Boko Haram. Consequently, the countries of the region pledged to contribute a battalion each to the MNJTF, while the partners committed to facilitate the early operationalization of the Regional Intelligence Fusion Unit (RIFU) and offered training to the Nigerian and regional forces engaged in the fight against Boko Haram and other terrorist groups $\left[{ }^{1}\right]$.

According to United Nations report, millions of people in Africa's Lake Chad region (north-east Nigeria and parts of Niger, Chad and Cameroon) are facing a profound and protracted crisis driven by extreme poverty, climate change and violent conflict. The crisis has led to the internal displacement of about 2.4 million people, the destruction of livelihoods, human rights abuses, and the disruption of health, education and other basic services. More than 10 million vulnerable people need life-saving assistance and protection today. Women and children are particularly hard hit. Nigeria's president Muhammadu Buhari, who recently chaired the Summit of Heads of State and Government of the Lake Chad Basin Commission (LCBC), was reported to have said in his address to the MNJTF troops that defeating Boko Haram is "a must-win war". The meeting of the Heads of State and Government of the LCBC which took place in N'Djamena, Chad, on December, 2018 was meant to review the progress so far made in the fight against Boko-Haram terrorist in the Chad basin.

It is therefore not out of place to say that following the decision made in Addis Ababa, Ethiopia by the Peace and Security Council of the African Union (AU) in March 2015 to authorize the deployment of the MNJTF and the approval of its Concept of Operations (CONOPS), one can say without mistaking that the MNJTF which led both by AU and LCBC at the strategic level and by a Force Commander at the operational level under its headquarters based in N'Djamena, Chad. Thus, the MNJFT enjoys the international legitimacy or the legal mandate required to eradicate the Boko Haram menace and any other forms of terrorism within the Lake Chad Basin area. However, what has not been properly addressed in most of the literature on the subject matter is the assessment of the MNJTF force in terms of its purpose and objectives. Especially taking into cognizance that Nigeria being the main victim of the insurgency had been the center piece upon which the regional security framework performs. The problem as addressed in this paper is how the countries of the region approached security challenges collectively. It appears that West African regional security order has not been designed effectively to handle activities of insurgent groups and other networks of criminals that cut across the region's international borders. In the Lake Chad region, Boko Haram and its offshoot ISIS-West Africa (ISIS-WA) since 2015 increased asymmetric attacks against civilians, government, and security forces, which resulted in deaths, injuries, abductions, and destruction of property. Consequently, Nigeria along with its neighbors: Cameroon, Chad, and Niger, often through the Multinational Joint Task Force, worked to counter these threats. This paper therefore, analyses the modus operandi of the Nigerian state through regional cooperation to tackle terrorist activities in the Lake Chad Basin region of West Africa. To do this, the paper looks at the bases for security cooperation between Nigeria and her neighbors in line with the ECOWAS security framework, the paper also analyzes both the effectiveness and ineffectiveness of Nigeria's engagement with the Joint Security Operations in the Chad Basin against Boko Haram and the socioeconomic impact of such regional security operation on the affected communities. The analysis contains in the paper leads to a prospective reflection on the future of 
these neighboring countries, considering the fact that the crisis has shaken the regional relationships that made the Lake Chad Basin resilient. The conclusion shows the need to restructure certain strategies for the regional security framework to be effective in West Africa.

\section{FRAMEWORK OF THE STUDY}

To understand Nigeria's place in regional security cooperation in West African sub-region one needs to look back at the country's involvement in the global arena since 1960. Since independence when the country pursued its foreign policy under the "Africa as center piece", Nigeria was at the forefront of anticolonial and liberation movements in the continent. Corollary to the pursuit of anti-colonialism is the active participation in the arena of global security, specifically its effort in regional peacekeeping operation. Of recent in Nigeria and indeed the entire West Africa, transborder security has become a serious challenge and a cause for concern amongst national governments in the sub-region and international organizations. The trend is multidimensional: from the complex security challenges, ranging from transnational organized crime, terrorism and proliferation of advanced and light weapons, to the simple and common security challenges featuring in the increase in kidnappings, armed robbery, drugs and human trafficking. More disturbing was the protracted and internationalized insurgent activities of Boko Haram elements of north-eastern areas of Nigeria. Over the course of less than two decades Boko Haram has morphed from a terrorist's movement operating within Nigeria to a movement with a regional presence across multiple countries in West Africa and beyond [6]. Undoubtedly, these criminal and terror activities, especially in Nigeria have been aggravated by the porous nature of the border areas of the country. According to Zenn [6] analysis, West Africa has progressively become a battleground for terrorist activities. More recently, Boko Haram has been striving to establish a Caliphate over a large part of Northeastern border region, killing thousands and forcing more than half a million civilians to flee their country [7].

Nigeria is very central in West Africa's security framework and specifically in the fight against Boko Haram because of number of reasons. With a population of about 200 million people, almost two third of the sub-region and being endowed with immense natural and human resources, Nigeria is destined to play leadership roles in the affairs of not only West Africa but the continent at large. Although successive Nigerian government has consistently accorded special attention to the plight and condition of her brothers and sisters in Africa which has made the basic principles of Nigeria's foreign policy "Afro centric", West African sub-region remains the first line of implementation. The perception of Nigeria in the maintenance of regional security in West Africa is hinged upon the belief that the country is the only regional power and its geographic location, its vast territory, its immense human and natural resources all give the country an incomparable power over the rest of West African countries. This is not only to ensure regional security in Africa but also to avoid a situation where African countries would become staging posts for external powers in order to maintain their global interests. Nigeria has never lost sight of the responsibilities entrusted on her by geography and circumstances. Being fully conscious of this, Nigeria has been careful to pursue any goal or objective that will be counterproductive to Africa's regional security. Thus,' the fundamental objectives of Nigeria's foreign policy clearly delineated her concerns for African regional security and development. These among others include: a) the creation of relevant political conditions in Africa and the rest of the world to facilitate the preservation of the territorial integrity and security of all African countries, while at the same time fostering national self-reliance and rapid economic development in Africa; b) promotion of equality and self-reliance in Africa and the rest of the developing world; c) Promotion and defence of justice and respect for human dignity, especially the dignity of the black man; and d) the defence and promotion of world peace.

The justification for the above discussion is due to the fact that the internal security of the individual states is central to the political stability, economic development, and good governance of the entire region. Bola Ate [8] argues that there cannot be any meaningful economic development in an insecure environment. It therefore follows that, if security constitutes a catalytic agent of economic development, then the management of security is it internal or external, can be interpreted to mean the management of the conditions for economic development [9]. The management of security in a country or region depends to a large extent, on the nature of the relationship between countries that are contagious to one another. Nigeria, as the largest and economically most powerful country in the West African sub region, has to reconsider its bilateral and multilateral foreign policies and diplomacy for managing the current security threats. Since 2011 Nigeria has been suffering from terrorists activities and the country could be said to be more vulnerable to threats than any other country in Africa. Having the largest population and market in West Africa, people of different background could enter the country for socioeconomic purposes from all over the world. Almost all the migration and security stakeholders seemed to agree that Nigeria's borders are porous and poorly monitored. The geo-strategic location of Nigeria in Africa, and the ethno-cultural linkages of Nigeria's border communities with neighboring countries not only lead to transnational trade, but also allow free flow of aliens into the country. Even more pertinent is the case of Nigeria's porous border which allows illegal drugs, encourages human trafficking, arms and ammunition 
and illegal oil bunkering [10]. Almost on the daily basis would one read or hear of migration-related offences and cross-border activities committed by Nigerians and non-Nigerians within and outside its borders.

Nigeria's commitment to the promotion of regional peace gave it a measure of autonomy in the pursuit of African genuine position in global politics. In fact, from 1960 to date, Nigeria had been involved in more than forty peacekeeping missions worldwide in both military and police roles which have been captured under the following remark: The commitment to global peace has continued to define Nigeria's foreign policy since her independence in 1960. And nowhere is it more evident than in Africa which has remained the cornerstone of her foreign policy. Today, Nigeria is the leading peacekeeping nation in Africa and has shown tremendous leadership in all regional and continental efforts in conflict management [11].

Just like Agwai postulates, the involvement of Nigeria in regional peacekeeping has to do with the commitment of its leaders since independence and for the determination to keep other nations from exercising strong influence on what it considers its sphere of influence [12]. Nigeria's peacekeeping record on the continent clearly define Nigeria's image as a major contributor to global security and indeed mark its contributions in that regard. In spite of these notable contributions there has been growing criticism especially at the domestic level on the rationale for such extraordinary human and material investment, particularly when the benefits accruable do not seem commensurate with the investment. Other issue of concern is on policy matters. Many are even querying the national or strategic interest served by pursuing such active regional peacekeeping role. Similarly, the strategy used by Nigeria in combating insurgency and terrorist activities in the region has been seriously challenged in the context of fast technological changes. Martha [13], has shown in her work that since 19/11, the issue of terrorism has become a major international security threat as a result there is shifting emphasis towards evolving new security and strategic frameworks that recognize the imperativeness of incorporating non-traditional elements of security in addressing these types of challenges. Thus, scholars increasingly formulate theoretical and conceptual frameworks that recognize the importance of other elements of security to a secured society. Notable among these is the recognition of the importance of regional integration, interdependence and alliances among nations as a form of security complex. In Africa, ECOWAS and its military wing, ECOMOG, provided an interesting example of how states build and operate a regional security structure that places regional security at par with their national security. This structure works very well, and has in many occasions in the past, served as quite useful in tackling regional security problems. Using this perspective, the paper will interrogate the following questions; what is the nature of Nigeria's cooperation with her neighbors in tackling terrorism especially in the Chad Basin area? What were the mechanisms put in place in the fight against terrorists activities that failed to end insurgency in the area? Why is it that there are increases in terrorists' attacks in spite of the presence of numerous regional and sub-regional joint task forces in the area?

\section{Development of Boko Haram and State's Response}

Boko Haram's history began in about 2003 in Kanama along the border with Niger and then in the Mandara Mountains in Cameroon with jihadists called the "Nigerian Taliban". Pursued by the Nigerian army, the group joined a radical Maiduguri-based preacher, Mohammed Yusuf. Yusuf was an indigene of Yobe state that subsequently developed the movement known today by the name of Boko Haram, a nickname coined by the indigenous people in 2006 and taken up by local journalists reporting on the first major clash with Nigerian security forces in 2009. The violence then escalated into a form of civil war with the declaration of a state of emergency in the BYA states: Borno, Yobe, and Adamawa in 2013, followed by the deployment of Multinational Joint Task Force (MNJTF) coalition troops in 2015. Equally, the rising scale of attacks by Boko Haram has been alarming to the extent of giving serious concern to international observers and security experts around the globe. As reported in a number of newspapers, the level of casualties, internal displacements, social disruption and government failure were becoming widespread crises spilling over the borders of neighboring states such as Niger, Cameroon and Chad. In fact, the US Department of States annual terrorism report for 2014 ranked the Boko Haram terrorists as first among the world's insurgent groups in terms of the number of fatalities [7].

However, Boko Haram had some followers in Niger, Chad, and Cameroon right from the group's beginnings. Nigeria's neighbouring countries were spared the fighting until 2014, since they served as a rear base for the insurgents, who had made a sort of mutual non-aggression pact with the local governments. Hence in 2015, Boko Haram extended its violent military operations without the influence of the sect itself. This extremely important point suggests that the group managed very early on to infiltrate the Lake's bordering countries' populations and conflicts to recruit followers. Behind the media stories of the sect's fragmentation over ideological divisions, it would therefore seem that there is not one Boko Haram group, but at least four groups corresponding to the different local dynamics that have determined the development of the insurgency in Nigeria, Niger, Chad, and Cameroon [6].

The internationalization of conflict has played out on two levels. First, there was the media coverage of the Chibok schoolgirls kidnapping in April 2014. 
Driven by the social networks and the Christian Association of Nigeria (CAN) lobby, the story quickly became a global issue and a symbol of a conflict that had remained largely unknown to the international community before that time. Yet the media spotlight on the Chibok girls kidnapping speaks volumes about the lack of knowledge of the area. The international mobilisation in support of the schoolgirls, who were not actually all Christians, gives the impression of differentiated treatment based on religion in a predominantly Muslim region. For example, the media had not mentioned the 50 Muslim schoolboys who were burnt alive in a dormitory fire incidence in a secondary school in Buni Yade, attacked by Boko Haram in Yobe State in February 2014. In the same vein, it took the media five months to spread the news of the kidnapping of three hundred Muslim children in Damasek in Borno State in December 2015 to the international community.

Paradoxically, the media sensation created by the Chibok affair gave Boko Haram an international profile which the sect did not previously have. The mobilisation to free the Chibok schoolgirls reveals most importantly the impotence of the Nigerian authorities, which initially denied the kidnapping. The affair became an electoral campaign argument in the 2015 presidential election. Combined with the kidnapping of a handful of Westerners in Nigeria and Cameroon in 2014, this forced Goodluck Jonathan's government to change attitude and call on its immediate neighbors and distant allies essentially the United States, France, and the United Kingdom to take action against global terrorism. Until 2013, the authorities had maintained that the insurgency was a simple matter of domestic unrest, in an attempt to guard against outside interference that risked exposing the abuses committed by the Nigerian army and the poor handling of the crisis by the security agencies $\left[{ }^{2}\right]$.

Between 2014 and 2015, the insurgents expanded their theatre of operations into the republics of Cameroon, Niger and Chad, as an anti-terrorist multinational coalition was set up. The highly fragmented group then retreated into the region's bush but continued to carry out attacks, particularly suicide bombings. Its capacity for resilience raises questions

2 . For instance, within a month of the state of emergency in the northeastern states, over 50 college students were killed as they slept in their hostels in the wee hours of the morning by the terrorists dressed as Nigerian soldiers. The suspected terrorists came to the campus with sophisticated machine guns, AK47s, machetes, and daggers that they had used in the attacks. It was erroneously believed by western media that the attack is part of the campaign to make sure Jonathan did not run for for another election when his term expires in 2015. See, Adrian Davieson, Boko Haram and its suicide Squad: the confession of a Jihadist, Lexington, KY, USA, 2014, P. 236. about the causes of the insurgency. The Boko Haram jihadist conflict has had various impacts in time and space. Borno in the north-east of Nigeria has clearly been the state the hardest hit by the violence. NUPI [14] reports that, nearly fifteen million civilians have been affected by the ongoing insurgency and resulting military operations, which have left 27,000 dead and more than 2.4 million displaced since 2009. As violence continues, governments are quick to claim that a victory to the war against 'violent extremist organizations' is within sight. Yet the conflict, with its nuanced drivers that run deeper than common narratives around violent extremism, in many ways has only begun. Numerous terrorist attacks occurred in different parts of Cameroon, Nigeria, Niger and Chad in 2017 [14]. The areas affected in Niger include Diffa and Tillaberi regions, leading to dozens of deaths and injuries. The worst of the attacks in Niger was in December 2019, when 73 soldiers were killed by the terrorist in Tilleberi. Terrorist organizations frequently stole military vehicles and equipment that they then used in later attacks. Terrorist attacks in western Niger focused almost exclusively on security forces, while Boko Haram and ISIS-WA attacked both civilian and military targets in the southeast. ${ }^{3}$ There have been attacks on both civilian and military targets by violent groups such as Boko Haram in Nigeria's northern borderlands. Boko-Haram's operations have been characterized by trans-boundary attacks in the Republics of Niger, Chad, and Cameroon. For instance, from 28 to 29 December, 2014, eighty-five civilians, ninety-four insurgents and two Cameroonian soldiers were killed in a Boko Haram attack on Cameroon's Far North Region [15]. February 6, 2015 witnessed Boko Haram raids on the towns of Bosso and Diffa in the Republic of Niger, killing several Nigeriens. In a related episode, on June 16, 2015, a Boko Haram's twin suicide bomb attacks in Chad capital, N'Djamena killed twenty four people and wounded more than one hundred others. On 16 March, 2016, a suspected Boko Haram suicide bomb attack killed at least 22 Muslim worshippers at a mosque in Maiduguri in north-east Nigeria, Independent, 16

${ }^{3}$. Other attacks include n June 28, two suspected Boko Haram suicide bombers attacked a refugee camp in Kabelewa, Diffa, killing three refugees and wounding 11 others. This was the first suicide attack in Diffa in more than one year. On July 2, Boko Haram terrorists kidnapped 39 women and killed nine civilians in N'Galewa village in Diffa region. On October 4, suspected ISIS-GS terrorists attacked U.S. and Nigerien Special Operations Forces in Tongo, Tillabery, killing four U.S. soldiers and five Nigerien soldiers and wounding two U.S. soldiers and four Nigerien soldiers. SIDA, (2018) Lake Chad Basin Crisis: Humanitarian Crises Analysis, https://www.sida.se/globalassets/sida/sve/sa-arbetarvi/humanitart-bistand/lcb-humanitarian-crises-analysis2018-final.pdf, accessed, 03/01/2019 
March, 2016. In May, 2014, Emir of Gwoza, Alhaji Idrissa Timta, a Muslim traditional leader, was killed when Boko Haram gunmen opened fire on his car in Zhur, Borno State. He was traveling in the company of two other emirs of Uba and Askira is Reuters, 30 May, 2016. While the sect's attack on mosques betrays its philosophy of Islamic purification, its hostility against the ruling aristocracy of northern Nigeria suggests a rebellion against the political status-quo [16].

Similar to other terrorist organizations, Boko Haram and its affiliates also began to recruit fighters including women from Cameroon and southern Niger. The group has so far gathered its strongest support among disaffected youth. In Cameroon, since at least as early as 2011, around 4,000 Cameroonian nationals were suspected to have joined Boko Haram in various roles including as fighters, spiritual guides and logisticians [14]. In Niger too, Yusufiyyah surrogates who returned to Diffa region from Maiduguri in neighboring Nigeria in the early 2000s, have recruited Nigerien youth into Boko Haram. While the massacre at Baga, on the Chad-Nigeria border with Chad in January 2015 drew international attention to Boko Haram's trans-boundary capabilities, limited focus is paid to the devastation that has been wrought outside Nigeria. Cameroon alone has experienced close to 500 Boko Haram attacks and 50 fatal suicide bombings [14].

Furthermore, Boko Haram and ISIS-WA carried out hundreds of attacks in Nigeria using suicide bombers, improvised explosive devices (IEDs), vehicleborne IEDs, raids, ambushes, and kidnappings $\left[{ }^{4}\right]$. African Union Security council reports that in 2017 Boko Haram continued to take advantage of weaknesses in Cameroon's border security to conduct terrorist attacks in the country's Far North Region, including suicide bombings, targeted killings, kidnappings, and raids in search of supplies[14]. Boko Haram perpetrated multiple and indiscriminate killings

4 . On June 7, suspected Boko Haram militants launched an attack on Maiduguri, Borno State, and engaged Nigerian forces in a gunfight. In coordination, three suicide bombers detonated explosives on civilian targets in the Muna Garage neighborhood of Maiduguri. The attack killed at least 17 civilians and injured 34 others. On July 25, an ISIS-WA attack on the Nigerian National Petroleum Company (NNPC) surveying project resulted in the deaths of at least 69 people. Victims included 19 soldiers, 33 civilian militia, and 17 NNPC and University of Maiduguri staff. Three university faculty were also abducted. On November 21, a Boko Haram suicide bomber detonated explosives at a mosque in the town of Mubi, in Adamawa State, killing at least 50 people. DTM, (2018), Lake Chad Basin

Crisis, https://www.sida.se/globalassets/sida/sve/saarbetar-vi/humanitart-bistand/lcb-humanitarian-crisesanalysis-2018-final.pd. accessed, 03/01/2019. against civilians, Muslims and Christians alike as well as against government officials and military forces. Although Cameroonian forces have become more effective at combating Boko Haram, dozens of attacks, often suicide bombings, occurred in $2017\left[^{5}\right]$.

United Nations Organizations (UNO) has outlined progress made against Boko Haram since the last Council briefing in September 2017, stressing that the Multinational Joint Task Force comprising military units from Benin, Cameroon, Chad, Niger and Nigeria have liberated hostages and made territorial gains. The Deputy Secretary of the UN emphasized that it is important to now stabilize reclaimed areas, and seize opportunities to promote sustainable development, especially as Boko Haram continued to carry out raids, abductions and suicide bombings. According to her, the United Nations was supporting the African Union and the Lake Chad Basin Commission in developing a resilient strategy, which she expected to be launched in N'Djamena.

In the same genre, Bande [8], further analyzes the Boko Haram insurgency in the context of the political economy of Lake Chad region. He shows how the insurgency had a negative impact on virtually every aspect of life in the Lake Chad region. The four Governments in the region resolved to protect civilians in the battle against that terrorist group and its ilk within a framework that also addressed development needs. Averting the shrinking of Lake Chad would require a dedicated international intervention, he said, emphasizing that the Lake one of the oldest in Africa was "very dear to our hearts" and a source of livelihood for more than 45 million people. Bande 2018, further emphasized that instability in the subregion could be traced to the Lake drying up, calling for rededicated international action, increased global attention and active engagement with Lake Chad region countries to speed up recovery efforts and address the root causes of terrorism, in line with resolution 2349 (2017) and the UNOWAS presidential statement adopted by the Security Council. This according to him would require strong United Nations cooperation with regional organizations such as the Economic Community of West African States (ECOWAS) and the Lake Chad Basin Commission, with the Organization providing adequate, predictable and sustainable funding for regional initiatives and Council-authorized peacekeeping operations.

5 . These included an attack in February that killed three soldiers, one in April that killed four vigilance committee members (vigilance committees are groups of ordinary residents who help protect the area from Boko Haram attacks), one in July that killed 14 people and wounded 32 others, and one in August that left 15 dead and eight abducted. In the very far northern area of the country, ISIS-WA conducted a few attacks, targeting military outposts, and generally refrained from killing civilians. Ibid. 


\section{Lake Chad Basin as a Fertile ground for Boko- Haram Terrorists}

The declaration of Boko-Haram as a foreign terrorist group in the heart of SubSaharan Africa in 2013 by US Home Land Security drew the attention of the World leaders, especially as the activities of the group spread to other neighboring countries: Chad, Cameroon, Niger and Benin. This development has endangered the relative peace and security situation in West African region [7]. Boko Haram insurgency has revealed the weakness of the governments of the four countries bordering the Lake. It has not evolved in a linear manner and really started to spread from Nigeria to Cameroon and Niger and Chad between 2014-2015. The conflict has had disastrous impacts on the population and economic activities. It has also fuelled major controversies over the causes of the insurgency, with debates that have sometimes had a major influence on the international community's military and humanitarian response agendas.

There had been the tendency to associate terrorist activities in the Lake Chad region to the nature and pattern of economy and geography of the area spinning many centuries. Lake Chad not only provides access to Nigeria but to other countries in West and Central African subregions, providing water for agricultural and domestic use, conservation and generation of hydro-electric power. Fishing is also a source of livelihoods for millions of Nigerians living along the Chad basin [7]. Proximity offers an opportunity to constructively engage other states and advance the cause of regional security cooperation. Interestingly, most of Boko Haram's attacks and recruitment around the area have mainly targeted the Lake region. It is argued that the group has exploited the history, the physical and human geography and the economic dynamism of this distinctive Lake environment, both a refuge from the pressure exerted by the region's national armies and a financial windfall. Boko Haram has also been able to draw on support, among local communities that are sometimes competing with each other and have a history of resisting external attempts to impose a political authority. The geographical, linguistics, religious and cultural proximity of Nigeria's Borno state which each year attracts large numbers of Chadian immigrants has facilitated its recruitment and the extension of the conflict to the Chadian shores of the Lake. Shrinking Lake Chad, caused mainly by global warning, now faces a new threat, having become the arena for a conflict between the bordering states and Boko Haram with the local population caught in the middle. The history of human settlement in this area helps to explain how the terrorist group established itself.

The Lake's recent history is characterised by the diversity of the population. In the twentieth century, its resources attracted new settlers which sparked competition for control of the Lakes Islands and the areas subject to seasonal flooding, a tendency that has been exacerbated by the current conflict. From Hausa migration to the Nigerian shores of the Lake in the early twentieth century to the arrival of fishermen from southern Chad or West Africa some decades later, many communities were drawn to the Lake, transforming it into an ethnic and cultural mosaic. With the water level sinking, new Islands have appeared and seasonal fishing camps have become villages, inhabited by local people but also government officials and soldiers. Over the past 40 years, due to this "race to the Lake", the net migration rate has been strongly positive in the region. The small Lake, which had 700,000 inhabitants in 1976, is today home to about 2.2 million, a dramatic increase of almost $300 \%$.

Boko Haram's success in establishing itself on the Lake and its recruitment of youths with few prospects despite the area's economic dynamism indicate the neglect of the peripheral areas by the governments of the region. The economic attractiveness of the Lake and its resources have created a trading hub, contrasting with the inadequacy and unreliability of the Lakeshore national governments' public policies. In Nigeria, the development policies of the 1970s and 1980s, such as major irrigation schemes like the old Baga Polder Project, created many jobs, particularly for Chadian migrants, yet had only limited success. In Niger, and even more in Cameroon, the Lake was regarded as a remote border area until the 1990s. In Niger, despite the construction of a road linking Diffa and N'Guigmi in 1975, it was not until the end of the 1990s that the state reestablished a serious presence in the Komadougou area. Today, although Diffa is much better equipped and richer than many other towns in Niger, the Nigerien villages near the Lake remain marginalized. In Cameroon, the Far North region became a focus of attention only recently, particularly because of the increase in the highway banditry. Often known as "N'Djamena's garden", the Lake and its polders (agricultural fringes) supply the city with fish and agricultural products. The headquarters of the Lake Chad Basin Commission (LCBC), which has official responsibility for managing the Lake's resources, are in N'Djamena. But yet, the Lake has some characteristics of a peripheral area, far from the centres of power. It was not until October 2015, after the attacks on Baga Sola, on the Lakeshore, that Chad's president visited the Lake for the first time in his life.

It has been further reported that over 20,000 people have been killed, more than 4,000 people have been abducted, 1.7 million remain displaced, mainly in Borno state, and over 200,000 Nigerians have fled to neighbouring countries [15]. The number of people estimated to be in need of humanitarian assistance in Borno, Adamawa and Yobe has been reduced from 8.5 million in 2017 to 7.7 million [15]. Displacement Tracking Matrix data (2018) also indicate that as of June 2018, Cameroon, Chad, Niger and Nigeria are 
hosting an estimated 4,187, 247 affected individuals made up of internally displaced persons (IDPs), refugees (both in- and out-of-camp), returnees (former IDPs and returnees from abroad) and third country nationals (TCNs). About $79 \%$ of the affected population (representing 3,322,297 individuals) are currently located in Nigeria, while $10 \%$ are located in Cameroon (417,607 individuals), $6 \%$ in Niger (252,305 individuals) and 5\% in Chad (195,038 individuals). Furthermore, an estimated 930,000 people still remain in areas controlled by Boko Haram and are cut off from basic services and humanitarian assistance. These people are, without any doubt, extremely vulnerable. In addition, women and child-headed households are considered to be amongst the most vulnerable including a higher risk of sexual and physical violence. Men and adolescent boys are at risk of forced recruitment by armed actors, arrest and detention, as well as being disadvantaged in terms of access to assistance because of suspicions that they might be members or supporters of Boko Haram. Experts on crisis in Lake Chad warned on the tension between refugees, internally displaced persons, returnees and host communities. People in the region had been welcoming, but tensions were exacerbated by a sense that humanitarian assistance was benefiting some, but not others. The report went on to show that the region had long suffered by weak governance, which had been heightened by the conflict. Looking to the future, new groups other than Boko Haram might emerge that could prove harder to combat.

\section{The 2015 Election of Muhammadu Buhari and the Fight against Boko Haram}

Since the 2015 general elections that brought Muhammadu Buhari into power, the activities of Boko Haram has been reduced significantly. The democratic changeover, which saw the replacement of one civilian regime with the other, was driven largely by fear of a Boko Haram's hostility to the government and general public. Boko Haram's attacks, the army's retreats, the corruption scandals, and the Chibok girls affair had in effect triggered such a feeling of national humiliation which had pushed voters, both Christians and Muslims alike, to vote for a retired military man whom they saw as being in a better position to deal with the terrorist challenge: Muhammadu Buhari. The battle against Boko Haram launched by the current government under President Buhari is yielding positive result, having decimated the activities of Boko Haram, reclaiming back territories once occupied by the Boko Haram group. Thus, his political will and determination to confront the activities of Boko Haram had restored confidence and moral support to the military to fight the Boko Haram terrorist group. To clearly understand the whole scenario, a review of the socio-political condition of Borno is important.
As far back as in 1950s the basic sociopolitical structure in Borno was Islam. This outcome was all the more that Borno has a bad lack of experience of multi-partyism in local politics. At independence, emirs manipulated the Native Authorities' police to crush their opponents, forcing the leaders of a short-lived Bornu Youth Movement to flee to Chad following clashes in Maiduguri in 1958 [17]. In 1999 , the end of the military regime also failed to put an end to political violence. Mala Kachalla (APP) was first elected in Borno State thanks to the financial support of Senator Ali Modu Sheriff, who had made his fortune doing business under General Sani Abacha's regime. In 2003, the then incumbent governor stood in vain on an Alliance for Democracy (AD) ticket. But he had to hand over to his "sponsor", who kept his grip on power for two terms until 2011. A highly controversial figure, Ali Modu Sheriff (ANPP) was accused of arming a private militia, called Ecomog, manipulating the issue of Sharia law, fuelling religious tensions, financing Boko Haram, and approving the extrajudicial execution of Mohammed Yusuf in order to eliminate a witness who might have exposed his fraudulent activities.

Kashim Shettima, Ali Modu Sheriff's former finance commissioner and successor, left no room for the local opposition either and was suspected of numerous conflicts of interest. Kashim is a graduate in agricultural economics from the University of Maiduguri and a former regional manager of Zenith Bank. He was quick to appoint his bank colleagues to key positions in 2011, with Yunus Marami in Finance and Adamu Lawan in Works and Housing. Zenith Bank also continued to manage Borno State's budget, even though it was a private group established by business tycoon Jim Ovia in 1990 who was particularly well connected with the corridors of power since the appointment of its former CEO, Godwin Emefiele, as the Governor of the Central Bank of Nigeria in 2014. In 2015, Muhammadu Buhari's presidential election victory effectively tightened Kashim Shettima's hold over Borno, but it also won the other North East states, which, with the exception of two of them, came under the control of the APC.

However, President Muhammadu Buhari's victory did score some points against Boko Haram. It immediately boosted the troops' morale. Even more importantly, it gave new hope to the people of Borno, who had felt abandoned by Goodluck Jonathan's government and who were now more willing to cooperate with the security forces, a vital prerequisite to fight an "invisible" enemy. Muhammadu Buhari, a Muslim from north-west Nigeria and a former military Governor of North-eastern state in 1975-1976, gave the impression of being more sensitive to the region's problems. Goodluck Jonathan's relationship with the governors of the Borno, Yobe Adamawa states had been disastrous, further complicating the ability to put in place a joint strategy against Boko Haram. 
Muhammadu Buhari, however, is on the same wavelength as the local authorities. On his election, he immediately took Kashim Shettima to accompany him on his official visits to the neighbouring countries.

Abroad, the new president was anxious to improve the coordination of the anti- terrorist coalition (the MNJTF) with Niger, Chad, and Cameroon. His reputation for integrity reassured the international community and, with crude oil prices plummeting, the drop in government revenues forced him to sign agreements with the World Bank and open the way for the arrival of more consistent humanitarian aid in northeast Nigeria. Paradoxically, the internationalisation of the response to the insurgents' threat also drove Boko Haram to seek foreign allies. In early 2015, a faction of the group pledged allegiance to ISIS. Yet its alliance hardly went any further than the actual recorded statement. On the military and financial front, it did not make the insurgents' operations more competent, there were no imports of more sophisticated weapons, and no exchanges of fighters with other terrorist groups in the Sahel or Libya. Instead, Boko Haram continued to operate like a low-cost insurgency, with very few resources.

Despite what President Muhammadu Buhari said in December 2015, the group was not "technically defeated." It did not stop attacking military positions, nor did it target civilians only, Pérouse de Montclos, 2017. Yet its suicide bombings, a weapon of the poor, proved particularly ineffectual. The emergence of Boko Haram and gradual spread of the conflict compared with other known cases in the world diminished as nearly one-third of the group's bombings missed their targets, claimed no fatalities, or killed only their perpetrator [18]. These failures were rarely due to technical problems. Furthermore, in pursuance of supports in the fight against Boko Haram terrorist group, the newly elected President of Nigeria, attended the 41st G7 summit in Germany to discuss the region security issue with the G7 leaders, who in turn pledged to assist Nigeria in its fight against the insurgent. What could be said about Nigeria's fight against terrorism currently is that, in practical terms, the group consequently lost ground and had to retreat to the Sambisa Forest and the marshlands of Lake Chad. At the same time, it continued to fragment into multiple factions. All in all, in 2018, Boko Haram was still not "technically defeated", and the insurgents' attacks, sporadic as they may be, continued to destabilise the entire region.

The Nigeria's Military Forces have carried out series of military operations against the Boko Haram, in a bid to step up its military operations against the insurgent; the Nigerian government relocated its Military Command Headquarters from the seat of power, Abuja, to Maiduguri, capital of Borno State, the epicenter of the insurgence. In addition, to enhance the regional joint military operations against the Boko Haram, the Nigerian government held a regional security summit under the Lake Chad Basin Commission in June in Abuja with affected countries: Chad, Niger, Cameroon and Benin, whereby the Nigerian government pledged financial support of One Hundred Million US Dollars to aid the operation of the multinational Military Joint Task Force (MNJTF) put in place to fight the threat of Boko Haram [6].

\section{CONCLUSION}

Nigeria's relationship with its immediate neighbors is the pivot around which to define and protect its national security interest in its essence. West African sub-region is vital for Nigeria's survival obviously because Nigeria's vital assets are located within it. For example, such vital assets are currently being put at risk because of the protracted contest in the Lake Chad area, the rich agricultural lands in the Mambila plateu, Bakassi Peninsula, including the Calabar river estuary, and the Bight of Biafra. Hence, there is substantial truth in saying that Nigeria's national security interest is intertwined with the entire systematic security in the sub-region. For this obvious reason, Nigeria has to reconsider the articulation of its security policies and strategies within and outside the country as they concern the possible partnerships with neighboring countries. Furthermore, regional planning should be very central to Nigerian state over the resilience of populations hit by the economic sanctions of the anti-terrorist coalition. In addition to this, Nigeria must treat this sub region as a natural base from which to project its national interests and regional influence. The fact that Nigeria needs not to play with the strategic significance of the North-East zone as a gateway to North-Central Africa and the Middle East in terms of diplomacy and future conflict, should be beyond focusing on the immediate problem of insecurity. Furthermore, there is the need for the new policy agenda for the sub-region which must take a serious account of the French position as a 'regional' actor. This does not mean that Nigeria should regard the presence of France as an inhibitive factor on Nigeia's policy. It means in the first instance, that we must be selective in determining the sectors of our bilateral collaboration with France in Nigeria so that, such collaboration will enhance, not undermine the objectives of our relations with the Franchophone countries. Language barrier as well as training

6. In addition to Nigeria's financial commitment, the US government has demonstrated its seriousness and commitment in the fight against terrorism in the region, the US Assistant Secretary, Bureau of African Affairs, Linda Thomas-Greenfield, announced at news briefing at the African Union Summit in June, 2015, that apart from training and support, they will also fledge financial commitment of five million dollars contribution to the Multinational Joint Task Force as well as some military equipment. 
techniques are serious problems among the MNJTF troops. Each country has training doctrines for its personnel and this affects operational tactics in the field. For instance, there is a difference in the operational doctrine of Anglophone oriented troops and their Francophone counterparts. Furthermore, communication is difficult between them due to the language barrier which tend to jeopardize the efficiency in their joint operations.

The most pertinent question to ask at this juncture is what the regional security forces can do to vanquish the group and its partners BH/ISWAP? It is apparent that MNJTF was able to disturb the activities of Boko Haram, affecting the group's trafficking routes, sources of income and supplies. This means that Boko Haram was left entirely defendant on its northern trafficking axis, the one that goes through Niger, Chad, Mali and Libya, a route strongly influenced by the Islamic State and its presence in Libya [19]. The best option for the MNJTF was therefore to widen the scope of membership and operation to include all those countries that share proximity to northern axis. MNJTF needs to reconsider its strategy. It appears that there is no common strategy to counter Boko Haram attack in the area. This current void in the successful renewal of Boko Haram attacks is a big weakness that the terrorists have been mercilessly exploiting. As this far-exceeds the Lake Chad region, the regional actors must now understand that what threatens their security is no longer at their door step, but much further away. It also means that without supra-regional cooperation, dealing with BH/ISWAP locally will amount to treating the symptoms but not the cause. In short, the security of Lake Chad region and Nigeria in particular is now directly linked to that of Libya, Democratic Republic of Congo or South Sudan. The fight against Boko Haram is therefore no longer regional but African [19].

There is the need also of involving other elements than the military into the fight against Boko Haream, such as police and state security Services that are already on site. It is a short term solution, but these security branches have the resources and the skills to create pressure on terrorists while the military reorganizes itself. The second element is to have a real MNJTF bound by a common strategy and goal, with a structure that will actually allow joint operations and use tactics maximizing the strengths of the units involved. The five-member state Multi-National Joint Task Force (MNJTF) should be empowered with the required human and material resources to manage the insurgency. Countries: Chad, Niger, Cameroon, Benin and Nigeria which constitute the MNJTF should demonstrate the political will to keep to the rules of engagement on the MNJTF agreement, as that would be crucial to the success of the task force. It is also vital that this regional cooperation goes beyond the military. It must involve police, border units, intelligence, surveillance and civil society groups to make sure that the insurgents do not simply cross the border, but actually have no place to hide or to fall back to. At this point, Nigeria and other regional states have been unable to contain Boko Haram, and now that it is becoming a fully regional entity, containment has become all the more difficult. It is nonetheless imperative that it be achieved. Finally, it is essential that decision makers in the area understand the interconnections which allowed the Islamic State and Boko Haram to expand as they did and to become supraregional factors. The civil war in Libya and the conflict in Mali, to name but two, are directly affecting the security of dozens of African states, as does the conflict in Nigeria. Understanding that "their problem is my problem" is key to making sure that the various streams and pockets which allow organizations like ISWAP to develop and become sustainable are dried up and make them vulnerable to defeat.

\section{REFERENCES}

1. Scott Menner. Boko Haram's Regional CrossBorder Activities, October, 2014. October 2014, Volume 7, Issue 10

2. Magrin G and Periose de Montecalos (eds.), Crisis and Development: The Lake Chad Region \& Boko Haram, Agence Fraincaise de development, AFD, rue Roland Barthes, Paris, August; 2018.

3. African Union, Report of the AU Chairperson of the Commission on Regional and International Efforts to Combat the Boko Haram Terrorist Group and the Way Forward, available at: http://www.peaceau.org/uploads/psc-484-rpt-bokoharam-29-1-2015.pdf], accessed 15/12/2018.

4. Pulse Nigeria. 'Full story of how Boko Haram killed 100 Nigerian soldiers in Borno; 2018.', https://www.pulse.ng/news/local/full-story-of-howboko-haram-killed-100-nigerian-soldiers-inborno/zgv9wwp

5. Independent. 'Nigeria mosque bomb: 'Boko Haram' suicide attack kills at least 22 worshippers in Maiduguri'.2016; Available from http://www.independent.co.uk/news/world/africa/ni geria-maiduguri-mosque-bomb-boko-haramsuicide-attack-kills-worshippers-a6933866.html. $<19$ July, 2016>.

6. Zenn J. Boko Haram Beyond the Headlines: Analysis of Africa's Enduring Insurgency, West Point; 2018. May 15, www.spearide.wordpress.com, retrieved, 08/10/2018.

7. Akinola W. Boko Haram is World Leader in Fatalities, Lagos, and Vanguard News Publication. 2015; June 21.

8. Bande TM. 'Multilateral Water Organizations and Nigeria's National Interest: Lake Chad Basin Commission and Niger Basin Authority', in A.M. Jega \& J.W. Farris, Nigeria at Fifty: Contributions to Peace, Democracy \& Development, Shehu Musa Yar Adua Foundation, Abuja. 2010; 205-228. 
9. Ate BE.'Nigeria's Relations with its immediate neighbors: A Security-Political Analysis' in B.E. Ate\& B.A. Akinterinwa, (eds.), Cross-border Armed Banditry in the North East: Issues in National Security and Nigeria's Relation with its Immediate Neighbors, NIIA, Lagos; 2011: 85-94.

10. Garuba DS. "Trans-Border Economic Crimes, Illegal Oil Bunkering and Economic Reforms in Nigeria", Global Consortium on Security Transformation, Policy Brief Series. 2010; (15).

11. Agwai A, Guven I, Madenci E. Predicting crack initiation and propagation using XFEM, CZM and peridynamics: A comparative study. In2010 Proceedings 60th Electronic Components and Technology Conference (ECTC). 2010: 1178-1185. IEEE.

12. Okolie CN. Trade unionism, collective bargaining and nation building: The Nigerian experience. OGIRISI: a New Journal of African Studies. 2010;7(1):136-48.

13. Maruping M. Challenges for regional integration in Sub-Saharan Africa: Macroeconomic convergence and monetary coordination. Africa in the World Economy. 2005;129.
14. Connor G. 'Violent Extremism'in the Lake Chad Basin: Understanding the Drivers of the Boko Haram Insurgency. NUPI Report. 2017.

15. SIDA. Lake Chad Basin Crisis: Humanitarian Crises Analysis;2018. https://www.sida.se/globalassets/sida/sve/saarbetar-vi/humanitart-bistand/lcb-humanitariancrises-analysis-2018-final.pdf, accessed, 03/01/2019

16. Faleye OA. "The Eco-Social Dynamics of NigeriaNiger Trans-Border Relations" in A.M. Ashafa, (eds.) Readings in Post-Colonial Borders and Economy in West Africa, Pyla-mak Services, Kaduna. 2018; 187-188

17. Cohen SS. Introduction to the Polyamines; 1971.

18. Warner J, Matfess H. Exploding stereotypes: The unexpected operational and demographic characteristics of Boko Harams suicide bombers, Combating Terrorism Center. ctc. usma. edu/report-explodingstereotypes-the-unexpectedoperational-and-demographic-characteristics-ofbokoharam s-suicide-b omb ers. 2017.

19. Bokeriya SA, Omo-Ogbebor OD. Boko Haram: a new paradigm to West Africa security challenges. Vestnik RUDN. International Relations. 2016 Dec $15 ; 16(2): 274-84$. 